\title{
Gender Equality and Modernity in Portugal. An Analysis on the Obstacles to Gender Equality in Highly Qualified Professions
}

\author{
Lígia Amâncio $^{1,2, *}$ and Maria Helena Santos ${ }^{1} \mathbb{D}$ \\ 1 Departamento de Psicologia Social e das Organizações, Instituto Universitário de Lisboa (ISCTE-IUL), \\ CIS_IUL, Avenida das Forças Armadas, 1649-026 Lisboa, Portugal; helena.santos@iscte-iul.pt \\ 2 Centro Interdisciplinar de Estudos de Género, Instituto Superior de Ciências Sociais e Políticas, \\ Universidade de Lisboa (CIEG/ISCSP-ULisboa) Campus Universitário do Auto da Ajuda, Rua Almerindo \\ Lessa, 1300-666 Lisboa, Portugal \\ * Correspondence: ligia.amancio@iscte-iul.pt
}

check for updates

Citation: Amâncio, Lígia, and Maria Helena Santos. 2021. Gender Equality and Modernity in Portugal. An Analysis on the Obstacles to Gender Equality in Highly Qualified Professions. Social Sciences 10: 162. https://doi.org/10.3390/socsci10050162

\section{Academic Editors: Anália Maria}

Cardoso Torres and Fátima Maria de Jesus Assunção

Received: 16 February 2021

Accepted: 2 May 2021

Published: 5 May 2021

Publisher's Note: MDPI stays neutral with regard to jurisdictional claims in published maps and institutional affiliations.

Copyright: (c) 2021 by the authors. Licensee MDPI, Basel, Switzerland. This article is an open access article distributed under the terms and conditions of the Creative Commons Attribution (CC BY) license (https:// creativecommons.org/licenses/by/ $4.0 /)$.

\begin{abstract}
In this review article, we argue that the transformations related to the modernisation of Portuguese society triggered by the implementation of democracy did not fully accommodate gender equality. In particular, when we consider the areas where the most progress has been made in keeping with a broadly shared urge for modernisation, education and science; whereas women have contributed to boosting the Portuguese population's level of education, thus inverting the worst legacy of the dictatorship and developing scientific research, gender inequalities are still visible in highly qualified professions. Reviewing the results of studies from different professions, science, medicine and engineering, our analysis illustrates several factors that hinder not only the recognition of women's competences and merit at work but also their career opportunities. Some of these factors are rooted in the type of gender ideology that was central to the propaganda of the dictatorship, thereby establishing continuity with the previous regime that seems particularly difficult to break in the absence of women's voices to raise awareness on gender equality.
\end{abstract}

Keywords: gender; equality; modernity; professions; work

\section{Introduction}

In the 20th century, Portugal experienced a long period of cultural backwardness, political repression and economic underdevelopment under a dictatorship, which lasted from 1926 to 1974 . Hence, the subsequent political process of consolidating democracy, and other social and economic transformations, aimed at changing the country from "a backward, socially underdeveloped country into a modern nation" (Pinto 1998, p. v). However, the demand for modernization that came with the transition to democracy and guided most of the first generation of social science research was "accompanied by the parallel reification of backwardness" according to Fróis (2012, p. 89). Considering that modernisation processes occur at different paces in different domains of life in society, we argue in this article that the ideology on equality between women and men lagged behind other social changes that occurred in the transition to democracy. Our underlying assumption is that the absence of debate on women's rights and gender inequalities in the early years of democracy hampered the development of awareness about gender equality in a democratic society. This paper reviews previously published studies by several Portuguese researchers, including the authors' own outputs, whenever possible combining statistics to set the context alongside interview data to identify the level of awareness and understanding of gender inequalities. Given the importance of the division of household work to working women's careers and opportunities, this section is preceded by a review of the main findings of recent surveys on the division of household work in Portugal. In our closing section, we summarize the findings presented in the previous 
sections and explore possible explanations for the level of gender discrimination awareness and initiatives to counter its limitations.

Women's civil rights were harshly limited and repressed under the dictatorial regime. In the article on equality of rights in the 1933 Constitution women were explicitly excluded as a result of their 'roles' in the family (Beleza 2015). Beyond its legal expression, the subordination of women and children in the family and the patriarchal values of obedience and submission to the 'head' of state and 'head' of family became an ideology touted in the dictator's speeches (Pimentel and de Melo 2015), taught in school manuals and further trained by fascist inspired youth and feminine organisations (Pimentel 2000). In the early years of democracy profound changes were introduced in legislation which extended women's rights and citizenship in the fields of voting rights, divorce and access to professions, such as the judiciary and diplomacy that were previously barred to them. Working rights and protection against gender discrimination were recognized and broadened as the country adopted and ratified the legal frameworks of international organisations such as the Commission on the Status of Women of the United Nations, the Council of Europe and the European Economic Community (the European Union today), which Portugal joined in 1986. However, as recalled by Beleza (2015, p. 18), the "long lasting effects of the discriminatory legal dispositions go well beyond their formal revocation".

One of the most devastating legacies of the dictatorial regime was education. In the 1960 s, more than $40 \%$ of the population could neither read nor write and only $0.6 \%$ had attained higher education (Barreto 1996). However, the improvements in education by the democratic regime did not close the gender gap in illiteracy given that thirty years later the rate of illiterate women (21\%) was still twice as high as that of men (11\%) (Nogueira et al. 1995, p. 210). As stated in that article, by prioritising the building of a universal system of formal education for the new generations, democratic governments left behind the eradication of illiteracy, thus maintaining the gender gap and creating a generational gap in educational skills among women. The rapid progress of women in formal education was reflected in the 1991 population census, which reported $48 \%$ of the population with higher education qualifications were women and they were also the majority of graduate students (53.9\%) (Nogueira et al. 1995, p. 211). Furthermore, women continued to progress in education with sociological research showing how educational credentials represented a necessary condition for women's intergenerational mobility while the same did not apply to men (Mendes 1998). In recent European statistics on education and science (European Commission 2019), women formed the majority of PhD holders and Portugal surpassed the average of EU countries in this indicator.

In conjunction with these, education, economic and social changes, the increasing proportion of women in the economically active population is an example of the country's social progress. Whereas in 1960, only 13\% of women were economically active, this number had risen to 29\% in 1981 and reached 41\% in 1991 (Almeida 1998, p. 149). However, this rapid increase in women's activity rate does not interlink with a women's movement. At the time the second wave feminist movement was making women's voices heard in other western countries, Portuguese society was going through a period of paralysation interrupted only by student uprisings followed by waves of repression. Additionally, in the early 1970s, the publication of New Portuguese Letters by three women writers, a founding book of Portuguese second wave feminism (Tavares 2011) was immediately followed by its banning. The drafting of young men for long periods of military service deployed in Africa during the colonial war (1961-1974) where many died, or were wounded, disrupted family life, and intimate relations. As a consequence of this war effort, poverty increased, migration to the urban areas grew rapidly coupled with mass emigration to other European countries, mostly of men, which reached its peak in the 1960s (Torres et al. 2004), leaving some rural areas almost deserted. In spite of the heavy prevailing ideology perceiving women mostly as wives and mothers their activities as paid workers to provide for the family became largely accepted in the absence of men. The transition to democracy added legal and political conditions to a set of historical conditions that converged to 
place women in a strong position in the active population (49.5\% in 2020) (Pordata 2021). Although the high activity rate of women, independent of their family status or number of children, remains a characteristic of Portuguese society, it does not amount to evidence of equality between women and men. On the contrary, patterns of sexual segregation, discriminatory and misogynistic attitudes, in the structure of employment, were identified by Ferreira (1998), and a persistent gender gap in salaries, despite the rise in qualifications of women. According to a recent report, the pay gap remains a worrying indicator of gender inequality. In 2018, Portugal occupied the 7th lowest position in the ranking of EU countries with a pay gap of $16 \%$ (European Parliament 2020) and European Institute for Gender Equality (EIGE) indicates that, contrary to the general tendency of reduction, the gender pay gap in Portugal has increased by more than 3\% since 2007. Disadvantageous working conditions for women are tolerated by society and women in particular, as highlighted by Ferreira (1998), as the result of an emancipation process that was made top down, through legislation (Ferreira 1999) and not with the active participation of women.

Tolerance to unworthy treatment was reported by the first survey on sexual harassment in the workplace. In 1989, the Commission for Equality at Work and Employment (CITE) of the Ministry of Work and Employment commissioned a national survey on sexual harassment with a representative sample of working women (Amâncio and Lima 1994). This bold initiative, which met strong resistance in public opinion for unveiling the taboo of sexuality, aimed at providing an extensive picture of sexual harassment in the workplace, to identify and characterise the problem in order to take political action. The results showed that one in three working women (34\%) had been sexually harassed, mostly by co-workers, followed by managers, but also revealed conflicting perceptions of sexual harassment in the case of innuendos. The most common reactions, in this case, were to dismiss and ignore the comments. At the time, this was interpreted as a result of a behaviour that was so pervasive in society that women tended to accept it as 'normal'. Twenty-five years later, CITE commissioned a national survey on moral and sexual harassment with a representative sample of working men and women (Torres et al. 2016). By using the same items to measure the perception of sexual harassment behaviours and types of reactions, this second survey included a comparison with the results obtained by the first version. While reporting sexual harassment was down to $14.4 \%$, this still identified "the persistence of a non-egalitarian vision of sexual encounters" in the workplace, expressed now mostly by hierarchical superiors (Torres et al. 2016, p. 79). Other indicators displaying significant changes: “ . . comparing the 1989 findings with those in 2015, ( . . ) changes which have taken place in Portuguese society over the intervening 25 years are revealed in the way women of working age are now more aware of their rights as women, citizens and workers. Two specific trends can be identified: women show greater clarity in identifying situations of sexual harassment, and women who suffer sexual harassment are better able to react (from doing nothing to immediately showing their annoyance)" (Torres et al. 2016, p. 87). These results indicate the persistence of behaviours that are highly damaging to women's self-esteem and integration in the workplace together with an increase in the awareness and capacity to deal with them. However, sexual harassment is still perceived as a relational problem rather than a manifestation of asymmetrical power.

\section{Changes and Continuities in the Division of Household Work}

In family life, a highly traditional division of household work persists, imposing a heavy burden on women, especially in dual-career couples (Wall et al. 2001), which coexists with non-traditional attitudes towards marriage, divorce and sexuality (Torres et al. 2013). Concerning the division of household work, the 2002 Family and Changing Gender Roles survey of the International Social Survey Programme (ISSP) returned significant differences between the time Portuguese women and men spent per week on household work with the former working more hours than the latter (Amâncio 2007). This pattern was common to the seven European countries included in this comparative study but the difference between the hours spent by Portuguese women (26) and men (7) was the highest. 
Comparing the data for dual-career couples, Portuguese women 'only' worked twice as many hours per week than men, contrary to more significant reductions in hours spent in household work by working women in other countries. Furthermore, in the measure for the perception of justice, Portuguese women reported the highest score for the item 'I do my fair share of the work'. In our perspective, two contradictions in the modernisation process account for the weak progress regarding equality in household work. One is the educational gap between different generations of women, which left older and unqualified women available for domestic paid labour and unpaid work in the case of family members such as grandmothers. Later on, the older generations were replaced by immigrant women thus assuring the continuity of this kind of paid work. As a result, dual-career couples have not felt any great pressure to negotiate the division of household work. However, research to substantiate the specific contributions of low paid (or non-paid), poorly qualified women to the household economy and its dynamics is still lacking. Another contradiction stems from the prevalence of the belief in women's skills as wives and mothers within the scope of the feminine myth inherited from the past. This belief lies behind women's perceived duty to protect their husband's career and avoid instability in the family's dynamics, according to research into dual-career earners in highly qualified professions (Rosa 2013). More recently, we compared the data of the 2002 ISSP survey with data obtained in a 2014 survey (Amâncio and Correia 2019) that applied the same questions. The results showed a slight reduction in the number of hours spent by women but no significant change in the division of household work in Portugal. This pattern remains highly disadvantageous to women's working lives and careers while preserving the old gender order (Connell 2002) in the family. The same traditional gender order is revealed in attitudes to gender roles in the family obtained in 2014 that express strong agreement with the statement that 'the family is harmed when women work full time outside the home' (43\%) and agreement with the traditional male breadwinner-female housewife family model $(25 \%)$. As stated by the authors: "These results show the latent conflict between a standard of equality in family life ... and a certain nostalgia for a model of the conjugal division of paid and unpaid work, based on complementary roles and naturalizing gender specializations, which for decades was a hallmark of the ideology of the Estado Novo" (Wall et al. 2016, p. 33). The persistence of conflict between work and family, and in conciliating the difficulties arising are particularly experienced by women as detailed in a survey on the uses of time by men and women. In this survey, women reported lacking free time more often than men, whether for leisure or other activities, and expressed "feelings of guilt and anxiety for not being able to meet the expectations that are imposed on them by others or that they impose on themselves" (Perista et al. 2016, p. 45).

\section{Progress and Obstacles in Qualified Professions and Power Sharing}

In this section, we present a review of research on three qualified professions, science, engineering and medicine that share in common two aspects relevant for our analysis: they are all professions where men are dominant, numerically and symbolically, and they all require higher levels of educational attainment. We intend to show that, despite progressive legislation, a significant presence of women in the labour market and their level of educational attainment, equality between women and men still today remains a challenge. The case of politics with which the section closes, although not a qualified profession serves to illustrate the resistance against integrating women in democracy and highlighting changes in discourses on equality and discrimination.

The case of science is particularly interesting as the building of a science and technology system, the expansion of the higher education sector and the establishing of an academic career all came with democracy and share a relatively short history. In an extensive European report on gender equality in science, Portugal was praised for having "been extraordinarily successful in incorporating women into science departments, at universities and research institutions" (European Commission 2000, p. 9). In the first survey conducted with a representative sample of the Portuguese scientific community in the early 1990s, 
women represented $36 \%$ of the total and were significantly present in most scientific fields, except for engineering and agriculture (Amâncio and Avila 1995). However, this same first survey of the scientific community also reported the clustering of post-PhD women in the ranks of assistant professor and associate professor, while the percentage of full professors was almost four times higher (24\%) for men than for women (7\%). Additionally, no age or qualification differences between women and men could account for such imbalance according to analysis conducted by this study. Inequalities in academic careers indicated that Portugal was not so special after all (Amâncio 2003) as the loss of scientific competences throughout the academic career, referred to as the "leaky pipeline" in the report, was similar to situations in other European countries and in the USA (Epstein 1991). The evidence of inequalities in academic careers presented in the ETAN report (European Commission 2000) fuelled public debates and legislative reforms in some EU countries but not in Portugal.

Although the percentage of female full professors rose to $17 \%$ ten years after the first survey, the numbers have stagnated near $25 \%$ in recent years in spite of women representing more than $45 \%$ of the scientific community, according to statistics from the Ministry of Science, Technology and Higher Education. In our perspective, scientific and higher education institutions do not consider gender equality a strategic priority for three main reasons. Firstly, this stems from the lack of formal involvement with gender equality policies until at least 2018. In this year, the Portuguese government adopted a national 2018-2030 strategy for equality and non-discrimination and with the plan for gender equality part of this strategy with objective 4 addressing the higher education and science sector. Ever since the adoption of the first action plan for equality by the Portuguese government in 1998, this was the first time specific actions addressed universities and research institutions. Secondly, social science research into career obstacles and the reasons for the persistence of discriminated elites in science and higher education institutions is still very scarce (Amâncio 2005; Oliveira et al. 2010). Additionally, thirdly, because the integration of gender in research (Schiebinger 2014) is not deemed sufficiently relevant (Schiebinger and Klinge 2013).

Despite the increasing integration of women in traditionally male scientific domains of education, they remain under-represented in various training and professional areas. Data from the Association of Engineers indicate that women represent 21\% of the members while the fields of Electronics and Automation, Metallurgy and Metalworking and Civil Engineering remain almost exclusively male (Teixeira and Casaca 2020, Table 1, p. 71). The eight interviewees in this study recognize the existence of social barriers in the choice of their training field and often highlighted the role played by a male member of the family who helped them through school and encouraged them to choose engineering. Cultural factors, such as gender stereotypes are referred to as contributing to those barriers, as do social representations of what it means to be a woman or a man, the social roles they should play, the associated characteristics and the dominant ideals of femininity and masculinity that sustain gendered patterns of socialisation (Casaca and Johanne 2017). Saavedra (2010), an author who has extensively studied the engineering context in Portugal, indicates that until preadolescence the number of girls and boys interested in Science, Engineering and Technology is very similar. However, in adolescence there is a clear decrease in the number of girls opting for these areas of study. This shift reflects the influence of socialisation on the education and training choices of girls and boys and, consequently, on the professional opportunities open to women and men. In short, this "gendered socialisation shapes the educational and formative choices of boys and girls, limiting their aspirations and professional opportunities and contributing to the reproduction of the sexual segregation of professions" (Teixeira and Casaca 2020, p. 78, our translation). This socialisation influences the choice of higher education fields as shown by the knowledge indicator in the gender equality index published by the European Institute of Gender Equality (European Institute for Gender Equality (EIGE)). Although the overall score for Portugal has improved in the last years (61.3 compared with an average of 67.9 for the EU), women cluster in the fields 
of education, health, welfare, humanities and arts, which account for nearly $40 \%$ of their choices. Awareness of the consequences of losing the most talented students to certain fields of training and research has recently led the government to launch a programme destined to attract girls into the field of engineering. Additionally, the Lisbon School of Architecture, Engineering and Technology adopted an internal programme for equality (Gender Balance @ Técnico), which includes three main lines of action: initiatives at secondary schools in order to attract more girls to the institution's degrees, a measure to reduce the impact of parenthood on scientific careers exempting parents (mothers or fathers being equally eligible) from teaching for six months beyond the period covered by the legal parental leave, and awards for best practices attributed every year to two outstanding women engineers: a recent graduate and a professional. However, this institutional initiative in favour of equality in a scientific field strongly associated with men sets an example that remains isolated in the higher education sector.

In the professional context, expectations differ according to gender with men tending to be perceived as more competent in certain professional areas, such as engineering (Saavedra et al. 2014; Teixeira and Casaca 2020), politics (Santos and Amâncio 2016) and medicine (Santos et al. 2015), depending on the areas of specialisation, and women to be perceived as more suited to the arts, humanities and social sciences (Casaca 2006; Saavedra et al. 2013). According to Teixeira and Casaca (2020), these expectations receive support from stereotypical perceptions of men and women. In the case of the former, highlighting characteristics such as the capacity for logical and abstract reasoning, impartiality, objectivity, the natural inclination to handle technical equipment, to innovate and create devices and in the case of the latter, highlighting characteristics such as education, care, management of emotions and interactions with human beings. For this reason, a suspicion often emerges over women's skills and abilities to adapt to markedly masculine professions (Santos and Amâncio 2014). Santos et al. (2015) showed, for example, how the skills of female medical specialists are regularly questioned contrary to those of male medical specialists.

Studies based on interviews shed some light on the way young women anticipate their future in the profession and the strategies adopted by professional women to cope with the context. Saavedra and Araújo (2015) interviewed 102 women including secondary school (42) and university students (20), and 39 young and senior professionals (Saavedra et al. 2014). Secondary school girls' discourses anticipated difficulties in recruitment, associated with the prospects of maternity, adding that their strategy to counter this difficulty was investing in their school performance to obtain the best grades. University students and young professionals openly denied discrimination, emphasising recent progress and blaming women's behaviour for discrimination. These discourses sustained the authors' statement that "consciousness of discrimination was limited to a minority of participants" (Saavedra and Araújo 2015, p. 183). In the study with professional engineers, discourses focus on feminine and masculine stereotypical categories valuing masculine characteristics and devaluing feminine characteristics. The most frequent strategies are identification with the masculine characteristics that form part of the professional ideal and hiding femininity through dress codes, careful language and control of appearance. This strategy comes up as instrumental to avoid sexual harassment, obtain respect and recognition. Since the study did not unveil any predisposition to social change, the authors conclude by saying that "women in engineering careers ... seem to regulate their behavior and feelings through the internalization of certain cultural prescriptions based on the power of hegemonic masculinity" (Saavedra et al. 2014, p. 32).

The presence of strong barriers to women's aspirations have been also identified in medicine (Santos et al. 2015, 2016). In this case, the strong impediments, mainly sustained by the gender role ideology inherited from the dictatorship, protected the masculine ideal of this profession (Marques 2011) for some time. It was only in the 1990s that there was a significant increase of women in medicine (Pordata 2020) as a result of their success in entering the highly selective faculties of medicine. The year 2010 marked a turning point 
as the percentage of female doctors (50.2\%) exceeded that of male doctors (49.8\%), reaching $55.8 \%$ in 2019 , and in keeping with an internationally identified trend (Lapeyre and Feuvre 2005; Riska 2011; Rosende 2008). Nevertheless, this change has only taken place at the level of overall numbers as research continues to report strong imbalances within the profession. In Portugal (Machado 2003; Marques 2011), as in other countries, more female doctors work part-time and pursue 'feminine' specialist fields whereas men occupy the positions with the highest status and prestige.

Regarding horizontal segregation, data from the Portuguese Medical Association identify how, by the end of 2019, women were still over-represented in specialties related to the care of children and women, such as paediatrics $(71.7 \%)$, childhood and adolescent psychiatry $(78.3 \%)$, gynaecology and obstetrics $(64.5 \%)$, and under-represented in specialties generally associated with higher salaries and prestige such as orthopaedics $(11.7 \%)$, sports medicine $(13.2 \%)$ and cardio-thoracic surgery $(11.3 \%)$ or those dealing with male sexuality such as urology (6\%) (Medical Association 2020). These asymmetries were also reported in a study by Santos et al. (2015) that conveyed how gender influences the dynamics that develop in this professional context and contributes to the advantages of men over women even when they are in extreme minority conditions. This qualitative study based on interviews with 17 doctors, of whom nine were women, reported for example, how the skills of female medical specialists regularly get questioned but not those of male doctors. It also showed that women progress in the medical hierarchy with greater difficulty than men; and that family care and household work remain obstacles to their careers but not to those of their male colleagues. Confronted with this evidence, male doctors consider it a temporary "reminiscence of the past history of the country", without pointing out any path of change other than waiting for time to achieve this. Female doctors, on the other hand, particularly in specialties where they remain a strong minority, were focused on strategies to be accepted by their male colleagues and protect their self-esteem in working environments that can be very hostile to them as women. In this study, we also found strategies of body discipline very similar to those reported by women engineers above. Women doctors report refraining from using make-up and adopting dress codes to hide their femininity, and blaming other women who do not act like this for causing discrimination. Therefore, the prescriptive power of hegemonic masculinity (Connell 1995) is equally visible in the medical profession.

What stands out from this review is that women's recent access to traditionally male professions, often culminating from successful educational trajectories, tends to favour beliefs in individual achievement and the individual strategies necessary for inclusion and coping with discrimination. Under the double pressure of two ideals, the masculine ideal of the profession and the ideal of femininity (Amâncio 1995), women often engage in what Nogueira (2009) designates essentialist discourses, trying to enhance individual achievement and denying discrimination, which they do not recognize as structural. In this study, based on 18 interviews of women in positions of power, such as members of parliament, court judges, a union president, members of industrial administration boards and research leaders, the author identified two types of discourses in the descriptions of their personal and professional paths. The essentialist discourse, which was the most frequent (14 out of 18 cases) focused on the personal attributes and achievements in fighting against the obstacles met on the way up the ladder while denying the existence of gender discrimination. On the other hand, the resistance discourse, acknowledging the existence of gender discrimination as a source of experience and learning competencies to act against discrimination, was a minority view (Nogueira 2009).

However, interviews in the field of politics show some differences in discourses. In politics, the sharing of power and the struggle against inequalities between women and men met strong resistance as encapsulated by the long-lasting confrontation around legislation to promote quotas in politics (Santos and Amâncio 2012a, 2012b, 2016). In the first period of democracy, the participation of women in parliament was derisory as they accounted for less than 5\% of members of parliament (4.9\% in 1976) (Santos 2011) and 
remained so for the next twenty years until the percentage of women reached $12.2 \%$ in 1995 . Since then, it has been rising steadily to reach 38.7\% in the national parliament in 2019 and $42.9 \%$ in the European parliament (Espírito-Santo and Santos 2020). One of the reasons for this change was the growing relevance attributed to gender inequalities in power sharing on international democratic governance policy agendas, which influenced national political leaderships (Baum and Espírito-Santo 2012); another reason was the public debate that took place in 1998/1999 around the (failed) first attempt to adopt the quota system; and finally, the so-called "parity law" promulgated in 2006. All these changes have raised awareness of women's discrimination in politics as women engaged in the debate over the quota system both inside their political parties and in the media. This was reflected in the resistance discourses identified in interviews with 10 women members of parliament (Santos 2011), who recognized discrimination even when they did not favour the quota system.

This debate, which created a strong political divide, as right-wing parties favoured internal political party regulation, against what was seen as government interference and recruitment based on individual merit, even if merit is not a central asset in recruitment in politics (Espírito-Santo and Santos 2020), ended up with the approval of the "parity law" for electoral lists. Although parity in this law was a mere 33\%, it did not prevent political parties from adopting measures to keep women away from eligible positions and other misinterpretations. Hence the need to clarify some aspects of the legislation in 2017, while simultaneously extending the quota system to public and listed companies. In 2019 , a second revision raising parity to $40 \%$ was adopted. In spite of the widespread recognition that equality in political representation could never have been achieved without special measures, the idea of gender (and ethnic) quotas remains highly controversial often eliciting rejection in the case of these categories but not in other instances (Santos and Amâncio 2010). As we concluded from this study in which we inquired about participant agreement (or disagreement) with the application of quotas for gender and ethnic groups in employment, and for disabled people and the distribution of European funds to the regions, participants do not reject quotas in general (they were in favour of quotas for the regions and disabled people). People reject quotas only when they do not recognize unfair treatment requiring a tool for combatting social discrimination that is both structural and unfair.

\section{Final Remarks}

Following a successful trajectory through the school system and access to higher education, where they became the majority in the late 1990s women entered male dominant professions and encountered gender discrimination. Their traditional role in the family seems to remain constantly present in their lives as professionals. Firstly, at the time of recruitment, this represented a limitation on their competing with male candidates. Later on, as professionals engaged in their careers, they found that being mothers reduced their chances of progression. This might come as a surprise after having seen their merit and intellectual capacities recognized and gratified at school and university, in a country that had made significant progress in legislation on equality between women and men. However, the interviews describe how the generation that went through these changes in educational attainment and in legislation were ill prepared to deal with gender discrimination. Denial of discrimination was a common strategy found in women's discourses of their different professional contexts. Furthermore, sharing an ideology that divides women and men according to specific characteristics, competences and roles left these women struggling with their femininity in contexts of hegemonic masculinity. Reflexions on social change mechanisms, or predispositions toward women's collective activities, were not identified in their discourses. In professional contexts and cultures from which they used to be excluded and did not contribute to, women do not seem encouraged to assume their identity, express a critical voice, or point out alternative ways, in short, telling their story as put forward by Queiroz (2007) for the case of women in science. 
This weak awareness around gender equality stems from the absence of debates around gender discrimination in the early years of democracy (Oliveira et al. 2009), the censoring of manifestations of feminism (Cerqueira et al. 2016) and the late development of the academic fields of women's studies/gender studies or feminist studies (WGFS) that are associated with a strong feminist movement. In this first period of democracy, research in WGFS was practiced in the outer circles of departments and faculties, not recognized as an autonomous field, and placed in the marginal position reserved to feminist epistemology in academic knowledge, as identified by Pereira (2012), a position that was only accentuated in recent years by neoliberalism in higher education and research (Augusto et al. 2018; Pereira 2019). In their analysis of the unfavourable academic context for WGFS in Portugal, Pereira and Joaquim (2009, p. 115) highlight the "rigid disciplinary structure of degree programmes". The experience of interdisciplinary training and research that was associated with the master's course on women's studies, launched by the Open University in 1996, contributed to the debate on the academic context (Joaquim 2007) alongside the emergence of a new generation of researchers. In 2008, a PhD programme on feminist studies opened at the University of Coimbra. More recently, an interdisciplinary $\mathrm{PhD}$ programme on gender studies opened in Lisbon, organised by a consortium of two universities, the University of Lisbon and the Nova University of Lisbon and hosted by CIEG, the only existing research centre on gender studies, founded in 2012. All these initiatives will contribute to the emergence of a sense of community in academia, to strengthen the alliance with activism and to disseminate awareness about feminism and gender in the younger generations.

Progressive public policies and legislation played a crucial role in improving equality between women and men in Portugal. However, this legislation opened opportunities, not minds. Recent institutional changes created the conditions to open minds and allow us to hope that the next generation of qualified women will experience better conditions of integration and career progression in their professions.

Author Contributions: Conceptualization, L.A. and M.H.S.; methodology, L.A. and M.H.S.; validation, L.A.; formal analysis, L.A.; investigation, L.A. and M.H.S.; supervision, L.A.; writing-original draft preparation, L.A. and M.H.S.; writing-review and editing L.A. and M.H.S. All authors have read and agreed to the published version of the manuscript.

Funding: This research received no external funding.

Informed Consent Statement: Not applicable.

Acknowledgments: We are grateful for the thoughtful and detailed comments of reviewers on a previous version of the article that were very helpful to improving it.

Conflicts of Interest: The authors declare no conflict of interest.

\section{References}

Almeida, João Ferreira. 1998. Society and values. In Modern Portugal. Edited by António Costa Pinto. Palo Alto: SPOSS, pp. 146-61.

Amâncio, Lígia, and Luísa Lima. 1994. Assédio Sexual no Mercado de Trabalho. Lisboa: Comissão para a Igualdade no Trabalho e no Emprego.

Amâncio, Lígia, and Patricia Avila. 1995. O género na ciência. In A Comunidade Científica Portuguesa nos Finais do Século XX. Edited by Jorge Correia Jesuíno. Oeiras: Celta, pp. 135-62.

Amâncio, Lígia, and Rita Correia. 2019. In pursuit of equality. Perception of justice and household work division-Changes and continuities. Sociologia Problemas e Práticas 90: 77-94.

Amâncio, Lígia. 1995. Social identity and social change: The case of gender relations. In Gender, Management and Science. Edited by Lígia Amâncio and Conceição Nogueira. Braga: Universidade do Minho, pp. 33-42.

Amâncio, Lígia. 2003. Gender and science in Portugal. Portuguese Journal of Social Science 1: 185-98. [CrossRef]

Amâncio, Lígia. 2005. Reflections on science as a gendered endeavour: Changes and continuities. Social Science Information 44: 65-83. [CrossRef]

Amâncio, Lígia. 2007. Género e divisão do trabalho doméstico-O caso português em perspectiva. In Família e Género em Portugal e na Europa. Edited by Karin Wall and Lígia Amâncio. Lisboa: Imprensa de Ciências Sociais, pp. 181-209.

Augusto, Amélia, Catarina Sales Oliveira, Emília Araújo, and Carla Cerqueira. 2018. The place for gender research in contemporary Portuguese science and higher education policies within the context of neo-liberalism. In Gender Studies and the New Academic Governance. Global Challenges, Glocal Dynamics and Local Impacts. Edited by Heike Kahlert. Wiesbaden: Springer, pp. 107-28. 
Barreto, António. 1996. A Situação Social em Portugal, 1960-1995. Lisboa: Instituto de Ciências Sociais.

Baum, Michael, and Ana Espírito-Santo. 2012. Portugal's quota-Parity Law: An analysis of its adoption. West Europe Politics 35: 319-42. [CrossRef]

Beleza, Teresa. 2015. Prefácio. In Mulheres Portuguesas. História da Vida e dos Direitos das Mulheres num Mundo em Mudança. Edited by Irene Pimentel and Helena Pereira de Melo. Lisboa: Clube do Autor, pp. 13-22.

Casaca, Sara Falcão, and Lortie Johanne. 2017. Handbook on Gender and Organizational Change. Turin: International Training Centre/International Labour Organization.

Casaca, Sara Falcão. 2006. La segregación sexual en el sector de las tecnologias de information y comunicatión: El caso de Portugal. Sociología del Trabajo 57: 95-130.

Cerqueira, Carla, Rosa Cabecinhas, and Sara Magalhães. 2016. Gender and media. Where do we stand today? In Gender in Focus. (New) Trends in Media. Edited by Carla Cerqueira, Rosa Cabecinhas and Sara I. Magalhães. Braga: CECS, pp. 5-11.

Connell, Raywen W. 1995. Masculinities. Berkeley: University of California Press.

Connell, Raywen W. 2002. Gender. Cambridge: Polity Press.

Epstein, Cynthia Fuchs. 1991. Constraints on excellence: Structural and cultural barriers to the recognition and demonstration of achievement. In The Outer Circle. Women in the Scientific Community. Edited by Harriet Zuckerman, Jonathan R. Cole and John T. Bruer. New York: W.W. Norton \& Company, pp. 239-58.

Espírito-Santo, Ana, and Maria Helena Santos. 2020. The share of women in decision-making positions across different levels of government. Representation, 1-19. [CrossRef]

European Commission. 2000. Science Policies in the European Union: Promoting Excellence through Mainstreaming Gender Equality. A report from the ETAN Expert Working Group on Women and Science. Luxembourg: Office for Official Publications of the European Communities.

European Commission. 2019. She Figures 2018. Brussels: Directorate-General for Research and Innovation.

European Institute for Gender Equality (EIGE). 2019. What lies behind the gender pay gap? Gender Statistics Base. Available online: https:/ / eige.europa.eu/gender-statistics/dgs/data-talks/what-lies-behind-gender-pay-gap (accessed on 14 April 2021).

European Institute for Gender Equality (EIGE). 2020. The Gender Equality Index 2020. Key Findings for the EU. Luxembourg: Publications Office of the European Union.

European Parliament. 2020. Gender pay gap in Europe: Facts and Figures (infographics). Available online: https:/ /www.europarl. europa.eu/news/en/headlines/society/20200227STO73519/gender-pay-gap-in-europe-facts-and-figures-infographic (accessed on 14 April 2021).

Ferreira, Virgínia. 1998. Engendering Portugal: Social change, state politics, and women's social mobilisation. In Modern Portugal. Edited by António Costa Pinto. Palo Alto: SPOSS, pp. 162-88.

Ferreira, Virgínia. 1999. Os paradoxos da situação das mulheres em Portugal. Revista Rítica de Ciências Sociais 52-53: 199-227.

Fróis, Catarina. 2012. The fate of 'backwardness' Portuguese expectations over modernisation. Anthropological Journal of European Cultures 21: 89-113.

Joaquim, Teresa. 2007. Feminismos, estudos sobre as mulheres ou «para onde vai este barco?». In O Longo Caminho das Mulheres. Feminismos 80 anos Depois. Edited by Lígia Amâncio, Manuela Tavares, Teresa Joaquim and Teresa Sousa de Almeida. Lisboa: Dom Quixote, pp. 203-16.

Lapeyre, Nathalie, and Nicky Le Feuvre. 2005. Féminisation du corps médical et dynamiques professionnelles dans le champ de la santé. Revue Française des Affaires Sociales 1: 59-81. [CrossRef]

Machado, Maria do Céu Soares. 2003. A feminização da medicina. Análise Social 38: 127-37.

Marques, António Manuel. 2011. Masculinidade e Profissões: Discursos e Resistências. Lisboa: Fundação Calouste Gulbenkian.

Medical Association. 2020. Distribuição por especialidades, idade e sexo. Available online: https://ordemdosmedicos.pt/wp-content/ uploads/2020/01/ESTATISTICAS_ESPECIALIDADES_2019.pdf (accessed on 16 April 2021).

Mendes, José Manuel O. 1998. Class structure and intergenerational mobility in Portugal: The importance of gender and skills. In Shifting Bonds, Shifting Bounds: Women, Mobility and Citizenship in Europe. Edited by Virgínia Ferreira, Teresa Tavares and Sílvia Portugal. Oeiras: Selected Proceedings of the 3rd European Feminist Research Conference, Celta, pp. 315-28.

Nogueira, Conceição, Constança Paúl, and Lígia Amâncio. 1995. Women in management in Portugal: A demographic overview. In Gender, Management and Science. Edited by Lígia Amâncio and Conceição Nogueira. Braga: Universidade do Minho, pp. 207-18.

Nogueira, Conceição. 2009. Women in positions of power in Portugal: Contradictory positions and discourses. Journal of Women, Politics \& Policy 30: 70-88.

Oliveira, Joao Manuel, Sofia Neves, Conceição Nogueira, and Marijke De Koning. 2009. Present but Un-named: Feminist liberation psychology in Portugal. Feminism \& Psychology 19: 394-406.

Oliveira, João Manuel, Susana Batel, and Lígia Amâncio. 2010. Uma igualdade contraditória? Género, trabalho e educação das "elites discriminadas". Políticas e Circunstâncias. In A Igualdade de Mulheres e Homens no Trabalho e no Emprego em Portugal. Edited by Virgínia Ferreira. Lisboa: Comissão para a Igualdade no Trabalho e no Emprego, pp. 247-60.

Pereira, Maria do Mar, and Teresa Joaquim. 2009. Dossier women's, gender, feminist studies in Portugal. Tracing recent changes, challenges and debates. In The Making of European Women's Studies. Athena Report. Edited by Beerteke Waldijk, Mischa Peters and Elsa van der Tuin. Socrates Programme. Utrecht: European Commission, Universiteit Utrecht, vol. IX, pp. 115-18. 
Pereira, Maria do Mar. 2012. 'Feminist theory is proper knowledge, but ... ': The status of feminist scholarship in the academy. Feminist Theory 13: 283-303. [CrossRef]

Pereira, Maria do Mar. 2019. "You can feel exhaustion in the air around you»: The mood of contemporary universities and its impact on feminist scholarship. Ex aequo 39: 171-86. [CrossRef]

Perista, Heloísa, Ana Cardoso, Ana Brázia, Manuel Abrantes, Pedro Perista, and Eudelina Quintal. 2016. Os Usos do Tempo de Homens e Mulheres em Portugal; Lisboa: Comissão para a Igualdade no Trabalho e no Emprego. Available online: http://cite.gov.pt/ asstscite/downloads/publics/INUT_livro_digital.pdf (accessed on 3 May 2021).

Pimentel, Irene Flunser. 2000. História das Organizações Femininas no Estado Novo. Lisboa: Círculo de Leitores.

Pimentel, Irene, and Helena Pereira de Melo. 2015. Mulheres Portuguesas. História da vida e dos Direitos das Mulheres num Mundo em Mudança. Lisboa: Clube do Autor.

Pinto, António Costa. 1998. Preface. In Modern Portugal. Edited by António Costa Pinto. Palo Alto: SPOSS, pp. v-ix.

Pordata. 2020. Médicos: Total e por Sexo. Available online: http://www.pordata.pt/Portugal/Medicos+total+e+por+sexo-1966 (accessed on 14 April 2021).

Pordata. 2021. População Activa: Total e por Sexo. Available online: https://www.pordata.pt/Portugal/Popula\%c3\%a7\%c3\%a3o+ activa+total+e+por+sexo-28 (accessed on 14 April 2021).

Queiroz, Clara. 2007. Um caminho que seja seu. As mulheres e a ciência. In O Longo Caminho das Mulheres. Feminismos 80 anos Depois. Edited by Lígia Amâncio, Manuela Tavares, Teresa Joaquim and Teresa Sousa de Almeida. Lisboa: Dom Quixote, pp. 217-28.

Riska, Elianne. 2011. Gender and medical careers. Maturitas 68: 264-67. [CrossRef] [PubMed]

Rosa, Rodrigo. 2013. Casamento e Desigualdade. Lisboa: Imprensa de Ciências Sociais.

Rosende, Magdalena. 2008. Parcours Féminins et Masculins de Spécialisation en Médecine. Zurich: Editions Seismo.

Saavedra, Luísa, Alexandra M. Araújo, João Manuel de Oliveira, and Christine Stephens. 2014. Looking through glass walls: Women engineers in Portugal. Women's Studies International Forum 45: 27-33. [CrossRef]

Saavedra, Luísa, Alexandra M. Araújo, Maria do Céu Taveira, and Cristina C. Vieira. 2013. Dilemmas of girls and women in engineering: A study in Portugal. Educational Review 1: 1-15. [CrossRef]

Saavedra, Luísa, and Alexandra M. Araújo. 2015. Em discurso direto: A discriminação contra as mulheres engenheiras. Psicologia, Educação e Cultura XIX: 170-87.

Saavedra, Luísa. 2010. Assimetrias de género nas escolhas vocacionais. In Guião de Educação, Género e Cidadania: 3. ${ }^{\circ}$ Ciclo do Ensino Básico. Edited by Teresa Pinto, Conceição Nogueira, Cristina Vieira, Isabel Silva, Luísa Saavedra, Maria João Silva, Paula Silva, Teresa-Cláudia Tavares and Vasco Prazeres. Lisboa: Comissão para a Cidadania e Igualdade de Género, pp. 261-69.

Santos, Maria Helena, and Lígia Amâncio. 2010. A (in)justiça relativa da acção positive-A influência do género na controvérsia sobre as quotas baseadas no sexo. Análise Psicológica 28: 43-57. [CrossRef]

Santos, Maria Helena, and Lígia Amâncio. 2012a. Género e política. Análise sobre as resistências nos discursos e nas práticas sociais face à lei da paridade. Sociologia, Problemas e Práticas 68: 79-101. [CrossRef]

Santos, Maria Helena, and Lígia Amâncio. 2012b. Resistências à igualdade de género na política. Ex aequo 25: 45-58.

Santos, Maria Helena, and Lígia Amâncio. 2014. Sobreminorias em profissões marcadas pelo género: Consequências e reações. Análise Social 212: 700-26.

Santos, Maria Helena, and Lígia Amâncio. 2016. Gender inequalities in highly qualified professions: A social psychological analysis. Journal of Social and Political Psychology 4: 427-43. [CrossRef]

Santos, Maria Helena, Lígia Amâncio, and Patricia Roux. 2015. Numbers do not tell the whole story: Gender and medicine in Portugal. Women's Studies International Forum 53: 73-82. [CrossRef]

Santos, Maria Helena, Patrícia Roux, and Lígia Amâncio. 2016. Experiences et strategies de femmes investies dans un "monde d'hommes": Le cas de la politique locale portugaise. Sociologia Problemas e Práticas 82: 69-87. [CrossRef]

Santos, Maria Helena. 2011. Do Défice de Cidadania à Paridade Política: Testemunhos de Deputadas e Deputados. Porto: Edições Afrontamento.

Schiebinger, Londa, and Ineke Klinge. 2013. Gendered Innovations. How Gender Analysis Contributes to Research. Luxembourg: Publications Office of the EU.

Schiebinger, Londa. 2014. Scientific research must take gender into account. Nature 507: 9. [CrossRef] [PubMed]

Tavares, Manuela. 2011. Feminismos. Percursos e Desafios (1947-2007). Lisboa: Texto.

Teixeira, Catarina, and Sara Falcão Casaca. 2020. Assimetrias de género na(s) engenharia(s) em Portugal: Dinâmicas e desafios. Faces de Eva. Estudos sobre a Mulher 43: 61-81.

Torres, Anália, Bernardo Coelho, and Miguel Cabrita. 2013. Bridge over troubled waters. Family, gender and welfare in Portugal in the European context. European Societies 15: 535-56. [CrossRef]

Torres, Anália, Dália Costa, Helena Sant'Ana, Bernardo Coelho, and Isabel Sousa. 2016. Sexual Harassment and Bullying in the Workplace in Portugal. Lisboa: Comissão para a Igualdade no Trabalho e no Emprego, Available online: http://cieg.iscsp.ulisboa.pt/images/ PDF/Policy\%20Brief\%20-\%20Sexual\%20Harassment\%20and\%20Bullyng\%20in\%20the\%20workplace\%20in\%20Portugal.pdf (accessed on 3 May 2021).

Torres, Anália, F. V. da Silva, Teresa Líbano Monteiro, and Miguel Cabrita. 2004. Homens e Mulheres entre Família e Trabalho; Lisboa: Comissão para a Igualdade no Trabalho e no Emprego. Available online: http://cite.gov.pt/imgs/downlds/Homens_Mulheres_ Fam_Trab.pdf (accessed on 3 May 2021). 
Wall, Karin, Sofia Aboim, Vanessa Cunha, and Pedro Vasconcelos. 2001. Families and informal support networks in Portugal: The reproduction of inequality. Journal of European Social Policy 3: 213-33. [CrossRef]

Wall, Karin, Vanessa Cunha, Susana Atalaia, Leonor Bettencourt Rodrigues, Rita Correia, Sónia Vladimira Correia, and Rodrigo Rosa. 2016. White Paper-Men and Gender Equality in Portugal; Lisboa: Comissão para a Igualdade no Trabalho e no Emprego. Available online: http:/ / cite.gov.pt/asstscite/images/papelhomens/WHITE_PAPER_Men_and_Gender_Equality_In_Portugal. pdf (accessed on 3 May 2021). 